\title{
Rapid Screening for Relative Salt Tolerance among Chile Pepper Genotypes
}

\author{
Genhua Niu ${ }^{1}$ and Denise S. Rodriguez \\ Texas AgriLife Research Center at El Paso, Texas A\&M System, 1380 A\&M \\ Circle, El Paso, TX 79927
}

\author{
Kevin Crosby \\ Department of Horticultural Sciences, Vegetable and Fruit Improvement \\ Center, Texas A\&M University, College Station, TX 77845
}

\section{Daniel Leskovar \\ Texas AgriLife Research Center at Uvalde, Texas A\&M System, Uvalde, TX 78801}

\section{John Jifon \\ Texas AgriLife Research Center at Weslaco, Texas A\&M System, Weslaco, TX 78596}

Additional index words. Capsicum annuum, C. chinense, salinity tolerance, soil salinity

Abstract. Chile peppers are economically important crops in southern regions of the United States. Limited information is available on irrigation management with lowquality water or on salt-affected soils. The objective of this study was to determine the relative salt tolerance of 20 genotypes of chile peppers. In Expt. 1, seeds of selected pepper types (Anaheim, Ancho, Cayenne, Paprika, Jalapeño, Habanero, and Serrano) were germinated in potting mix and seedlings were grown in $2.6-\mathrm{L}$ pots. Six weeks after sowing, salinity treatments were initiated by irrigating plants with nutrient solutions of different electrical conductivities (ECs): 1.4 (control), 3.0, or $6.0 \mathrm{dS} \cdot \mathrm{m}^{-1}$. After 1 month of initiating treatments, shoots were harvested and dry weights were determined. All plants survived and no visual salt injury was observed regardless of pepper variety and treatment. There were no statistical differences between control and saline solution treatments in final height and shoot dry weight of Habanero 1, 'Early Jalapeño', 'AZ-20', 'NuMex Joe E. Parker', and 'NuMex Sandia'. In Expt. 2, seeds of 20 genotypes were directly sown in 2.6-L containers filled with loamy sand. Saline water irrigation was initiated 37 days after sowing by irrigating plants either with saline (nutrient solution based, similar to Expt. 1) or nutrient solution (control). More than half the genotypes did not have $100 \%$ survival in the salinity treatment. Ancho 1, Ancho 2, Cayenne 1, 'Early Jalapeño', and 'AZ-20' had $\mathbf{1 0 0 \%}$ survival regardless of salinity treatment. No plants of 'TAM Mild Habanero' survived when irrigated with saline water and less than half of the plants survived in the control. The relative tolerance of chile genotypes to salinity varied with substrate in some genotypes. From the combined results of the two experiments, the 20 pepper genotypes were ranked for salt tolerance based on seedling survival, visual quality, and growth. 'Early Jalapeño' and 'AZ-20' were relatively tolerant to salinity among the 20 genotypes, whereas 'TAM Mild Habanero' and 'Ben Villalon' were sensitive. Ancho 1, Ancho 2, Cayenne 1, and Cayenne 2 also had relatively high tolerance based on survival and visual quality, although shoot growth was reduced significantly.

Water shortages and poor water quality are critical issues in many regions of the world. With a rapidly increasing population and diminishing water supplies, the competition for fresh water among agriculture, industry, urban, and recreational users has

Received for publication 3 May 2010. Accepted for publication 19 June 2010.

We gratefully acknowledge the financial support from National Institute of Food and Agriculture, U.S. Department of Agriculture under Agreement No. 2009-34461-19772, and Texas AgriLife Research.

${ }^{1}$ To whom reprint requests should be addressed; e-mail gniu@ag.tamu.edu. within a species (Maas and Hoffman, 1977; Pasternak and Malach, 1994). Among horticultural crops, peppers are considered moderately sensitive to salinity (Pasternak and Malach, 1994), although some species/cultivars may be more tolerant than others. In New Mexico and western Texas, with a typical semiarid climate, high soil salinity often leads to poor stand establishment of highvalue crops such as chile peppers and onions (Allium cepa) (Corgan et al., 2000; Phillips, 2003).

One of the most effective ways to overcome salinity problems is the introduction of salt-tolerant crops. However, limited information exists for salt tolerance of various horticultural crops, including chile peppers. Earlier studies classified pepper as moderately sensitive to salt stress and yield began to decline once the soil electrical conductivity (EC) level exceeds $1.5 \mathrm{dS} \cdot \mathrm{m}^{-1}$ (Maas and Hoffman, 1977; Pasternak and Malach, 1994). However, limited recent studies have indicated that some genotypes are more tolerant to salinity than others. Substantial variations in the response of 102 pepper genotypes to salinity were observed in a greenhouse experiment based on the severity of leaf symptoms caused by $\mathrm{NaCl}$ stress at $100 \mathrm{~mm}\left(9.1 \mathrm{dS} \cdot \mathrm{m}^{-1}\right)$ (Aktas et al., 2006). Similarly, Chartzoulakis and Klapaki (2000) reported differences in two bell pepper hybrids, 'Lamuyo' and 'Sonar', in response to salinity based on growth and yield. Such evaluations may facilitate improvement of salt tolerance of pepper genotypes in breeding programs or it may prove feasible to irrigate with saline water for more tolerant genotypes. In addition, anecdotal observation indicated that it is more difficult for chile pepper seeds to germinate and establish in mineral soils compared with commercial potting mix. Elevated soil salinity and/or inadequate water supply can further reduce seedling establishment. The objective of this study was to evaluate the relative salt tolerance of 20 genotypes (Anaheim, Ancho, Cayenne, Paprika, Jalapeño, Habanero, and Serrano) of chile peppers in two separate experiments using potting mix and mineral soil based on seedling growth, survival, and visual quality.

\section{Materials and Methods}

Expt. 1. Seeds of 19 genotypes (Table 1) were sown in 72-cell trays filled with a germination mix (Sunshine Mix No. 5; SunGro Hort., Bellevue, WA) in a mist bench with reverse osmosis water $\left(\mathrm{EC}=0.0 \mathrm{dS} \cdot \mathrm{m}^{-1}\right)$ in the greenhouse. The average daily greenhouse temperatures were maintained at $24.0 \pm 1.3{ }^{\circ} \mathrm{C}$, relative humidity at $25 \pm 7.1 \%$, and daily light integral [photosynthetically active radiation $(P A R)]$, measured with a quantum sensor, was $11.2 \pm 2.5 \mathrm{~mol} \cdot \mathrm{m}^{-2} \cdot \mathrm{d}^{-1}$. Four weeks after sowing, seedlings were transplanted to 2.6-L plastic pots containing a similar potting mix with additional coarser perlite (Sunshine Mix No. 4; SunGro Hort.) and grown in the greenhouse irrigated with a nutrient solution at EC of $1.4 \mathrm{dS} \cdot \mathrm{m}^{-1}$ made by adding $0.5 \mathrm{~g} \cdot \mathrm{L}^{-1}$ of 20N-8.6P-16.7K (Peters 20-20-20; Scotts, 
Table 1. Final height and shoot dry weight (DW) of 19 chile pepper seedlings irrigated with nutrient solution (control) or saline solution (salt) for 4 weeks (Expt. 1).

\begin{tabular}{|c|c|c|c|c|c|}
\hline Genotypes & Type & $\begin{array}{l}\text { Ht control/salt } \\
(\mathrm{cm})\end{array}$ & $t$-test & $\begin{array}{c}\text { Shoot DW } \\
\text { control/salt }(\mathrm{g})\end{array}$ & $t$ test \\
\hline Ancho 1 & Ancho, $\mathrm{BL}^{\mathrm{z}}$ & $40.3 / 34.2$ & $* * * y$ & $5.9 / 4.7$ & $* * *$ \\
\hline Ancho 2 & Ancho, BL & $21.4 / 20.0$ & NS & $4.9 / 2.8$ & $* * *$ \\
\hline Cayenne 1 & Cayenne, BL & $30.2 / 24.7$ & $*$ & $6.8 / 4.6$ & $*$ \\
\hline Cayenne 2 & Cayenne, BL & $29.1 / 27.0$ & NS & $5.6 / 4.1$ & * \\
\hline Habanero 1 & Habanero, BL & $22.2 / 23.0$ & NS & $4.6 / 4.8$ & NS \\
\hline Jalapeño 1 & Jalapeño, BL & $35.9 / 29.0$ & $* * *$ & $7.4 / 6.1$ & NS \\
\hline Jalapeño 2 & Jalapeño, BL & $20.4 / 18.6$ & $* * *$ & $7.3 / 4.2$ & $* * *$ \\
\hline Paprika & Paprika, BL & $16.7 / 16.1$ & NS & $6.2 / 3.9$ & $* * *$ \\
\hline Serrano 1 & Serrano, BL & $62.9 / 48.9$ & $* * *$ & $10.3 / 8.1$ & * \\
\hline Serrano 2 & Serrano, BL & $32.0 / 26.9$ & $* * *$ & $8.0 / 4.8$ & $* * *$ \\
\hline Ben Villalon & Anaheim, CV & $22.3 / 16.8$ & $* * *$ & $8.2 / 3.7$ & $* * *$ \\
\hline TAM Mild Habanero & Habanero, CV & $8.8 / 8.5$ & NS & $4.2 / 1.6$ & $*$ \\
\hline Early Jalapeño & Jalapeño, CV & $9.5 / 10.2$ & NS & $2.9 / 2.5$ & NS \\
\hline AZ-20 & Anaheim, CV & $21.7 / 20.3$ & NS & $8.0 / 5.2$ & NS \\
\hline NuMex 6-4 & Anaheim, CV & $28.0 / 22.9$ & $* * *$ & $8.4 / 5.3$ & $* * *$ \\
\hline NuMex Joe E. Parker & Anaheim, CV & $20.8 / 20.7$ & NS & $6.7 / 4.9$ & NS \\
\hline NuMex Primavera & Jalapeño, CV & $18.3 / 18.4$ & NS & $5.6 / 3.7$ & $*$ \\
\hline NuMex Nematador & Cayenne, CV & $28.1 / 23.9$ & $* * *$ & $9.0 / 4.1$ & $* * *$ \\
\hline NuMex Sandia & Anaheim, CV & $26.2 / 24.1$ & NS & $7.8 / 5.4$ & NS \\
\hline
\end{tabular}

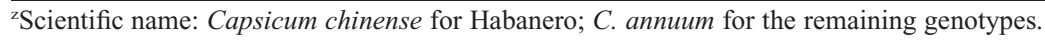

y*,**, ***, Ns indicates significant and nonsignificant at $P=0.05,0.01$, or 0.001 , respectively.

Green chile 1 was excluded because of low germination rate, which was not related to salt stress.

$\mathrm{BL}=$ breeding line; $\mathrm{CV}=$ cultivar.

Allentown, PA). Six weeks after sowing, saline irrigation treatments were initiated by irrigating plants either with nutrient solution (control) or saline solution. Saline solution was prepared by adding proper amounts of sodium chloride $(\mathrm{NaCl})$, magnesium sulfate $\left(\mathrm{MgSO}_{4} \cdot 7 \mathrm{H}_{2} \mathrm{O}\right)$, and calcium chloride $\left(\mathrm{CaCl}_{2}\right)$ at $87: 8: 5$ (by weight) to the nutrient solution. The initial EC of the saline solution was 3.0 $\mathrm{dS} \cdot \mathrm{m}^{-1}$ and elevated to $6.35 \mathrm{dS} \cdot \mathrm{m}^{-1}$ from the second irrigation and thereafter. To minimize differences in the environmental conditions such as temperatures, light and air current speed, etc., plants were rotated weekly as a group to keep the two treatments for the same genotype together on the greenhouse bench. The experiment was ended after 4 weeks of treatment when plants reached the flowering stage and shoots were harvested.

Expt. 2. Seeds of the same 19 genotypes used in Expt. 1 plus Green Chile 1 (Anaheim), which had low germination and was excluded in Expt. 1, were sown directly in 2.6-L pots filled with Bluepoint loamy sand (calcareous, Torripsamment, Entisol) collected from a field near the El Paso Research Center. All pots were flushed (10 times) with reverse osmosis water until leachate salinity was reduced to $0.9 \mathrm{dS} \cdot \mathrm{m}^{-1}$. Four seeds were then sown per pot and irrigated with tap water $\left(\mathrm{EC}=0.9 \mathrm{dS} \cdot \mathrm{m}^{-1}\right)$. The greenhouse environment was maintained at $22.3 \pm 1.7^{\circ} \mathrm{C}$, relative humidity at $31 \pm$ $8.5 \%$, and $P A R$ at $17.8 \pm 4.2 \mathrm{~mol} \cdot \mathrm{m}^{-1} \cdot \mathrm{d}^{-1}$. After germination ( $23 \mathrm{~d}$ after sowing), seedlings were thinned to one per pot and salinity treatments were initiated $37 \mathrm{~d}$ after sowing by irrigating plants with saline solutions at $3.0 \mathrm{dS} \cdot \mathrm{m}^{-1}$ or with nutrient solution. Two weeks later, salinity of the saline solution was elevated to $6.35 \mathrm{dS} \cdot \mathrm{m}^{-1}$ and continued thereafter. Seven weeks after treatments, the experiment was ended and shoots were harvested.

Measurements. To quantify the response of plant performance to salinity, plant height and leaf stomatal conductance $\left(g_{\mathrm{S}}\right)$ of the abaxial side were measured weekly for Expt. 1. For Expt. 2, height was recorded weekly and $g_{\mathrm{S}}$ was measured once near the end of the experiment. For both experiments, $g_{\mathrm{S}}$ was measured on sunny days using a leaf porometer (Decagon Devices, Pullman, WA). At the end of both experiments, shoots were harvested and fresh weight was recorded. Dry weights of shoots were determined after oven-drying tissues to a constant weight at $70{ }^{\circ} \mathrm{C}$. For Expt. 2, survival rates were recorded weekly and foliar salt damage was rated at the end of the experiment by giving a score from 0 to 5 to every plant, in which $0=$ dead, $1=$ over $90 \%$ foliar damage (salt damage: burning and discoloring), $2=$ moderate $(50 \%$ to $90 \%)$ foliar damage, $3=$ slight (less than $50 \%$ ) foliar damage, $4=\operatorname{good}$ quality with minimal foliar damage, and $5=$ excellent with no foliar damage. The size of the plant was not considered in scoring. For example, a score of 5 was given to the plants with normal foliage color and vigor, although they were small.

Leachate $\mathrm{EC}$ and $\mathrm{pH}$ were determined by a pour-through method (Wright, 1986). Briefly, $100 \mathrm{~mL}$ reverse osmosis water was added to the 2.6- $\mathrm{L}$ container $1 \mathrm{~h}$ after irrigation through the surface of the medium and leachate was collected and analyzed for EC and $\mathrm{pH}$ using salinity/pH meters (Model B-173; Horiba, Ltd., Kyoto, Japan). Analysis of leachate was conducted on three containers per treatment for each genotype.

Data analysis. The experiment was a split-plot design with saline treatment as the main plot and chile type as subplot. There were eight replicate plants per treatment for both experiments. Data were analyzed separately for each experiment by two-way analysis of variance using PROC GLM. When significant differences were observed among chile genotypes, the effect of salinity treat- ment on each individual genotype was analyzed by $t$ test. To compare EC and $\mathrm{pH}$ of the leachate among genotype, Student-NewmanKeuls multiple comparisons were performed at $P=0.05$ for the salinity treatment. The correlation between leachate $\mathrm{pH}$ and $\mathrm{EC}$ was analyzed by PROC CORR. All statistical analyses were performed using SAS (SAS Institute, 2002).

\section{Results and Discussion}

Growth, survival, and visual quality. For both experiments, salinity treatment and genotype had a significant effect $(P<0.0001)$ on shoot dry weight. Salinity treatment and genotype had an interactive effect on shoot dry weight. All plants in Expt. 1 survived without any visual foliar salt damage. There were no differences in final height between the plants irrigated with nutrient or saline solution in Ancho 2, Cayenne 2, Habanero 1, Paprika, 'TAM Mild Habanero', 'Early Jalapeño', 'AZ-20', 'NuMex Joe E. Parker', 'NuMex Primavera', and 'NuMex Sandia' (Table 1). For shoot dry weight, no differences were observed between the two treatments in Habanero 1, Jalapeño 1, 'Early Jalapeño', 'AZ-20', 'NuMex Joe E. Parker', and 'NuMex Sandia'. 'TAM Mild Habanero' had a reduction of $62 \%$ in shoot dry weight when irrigated with saline compared with nutrient solutions followed by 'Ben Villalon' and 'NuMex Nematador' both at 55\%, Ancho 2 at $42 \%$, Serrano 2 at $40 \%$, Paprika at $38 \%$, 'NuMex 6-4' at 37\%, and 'NuMex Primavera' at $34 \%$. For Habanero 1, 'Early Jalapeño', 'AZ-20', 'NuMex Joe E. Parker', and 'NuMex Sandia', saline water irrigation did not result in statistical differences in either final height nor shoot dry weight compared with the control plants.

In Expt. 2, more than half of the genotypes did not have $100 \%$ survival (Table 2 ). Survival rates of eight genotypes were less than $100 \%$ even under nonsaline conditions. In contrast, all plants of Ancho 1, Ancho 2, Cayenne 1, 'Early Jalapeño', and 'AZ-20' survived regardless of treatment. No plants of 'TAM Mild Habanero' survived when irrigated with saline solution and less than half of the plants survived in control treatment. Survival rates of Habanero 1 and 'NuMex Nematador' were low ( $38 \%$ and $33 \%$, respectively). The survival rates of Green Chile 1, Jalapeño 2, Serrano 2, and 'Ben Villalon' were $50 \%$ in response to saline treatment.

Foliar salt damage symptoms expressed as necrosis and chlorosis were observed on all genotypes, but the degree of damage varied among genotypes. Ancho 1, Ancho 2, 'AZ-20', and Cayenne 2 had scores above 4.5 in both treatments. When irrigated with saline solution, scores for paprika and 'NuMex 6-4' were between 3 and 4, whereas all other genotypes below 3. Among these low-score genotypes, 'TAM Mild Habanero', 'Ben Villalon', Habaneo 1, Serrano 2, 'NuMex Joe E. Parker', and 'NuMex Sandia' had scores below 2.

Plant performance was generally poor in loamy sand in Expt. 2 for all genotypes 
(Tables 1 and 2). Among the five genotypes with $100 \%$ survival, shoot dry weight of 'AZ20 ' and 'Early Jalapeño' was not significantly affected by the saline water irrigation (Table 2). However, shoot dry weight of Ancho 1, Ancho 2, and Cayenne 1 was reduced by $42 \%, 38 \%$, and $49 \%$, respectively, when irrigated with saline solution compared with nutrient solution. Although no statistical differences were found in shoot dry weight between the treatments, Green Chile 1, Jalapeño 2, and Paprika did not grow well even when irrigated with nutrient solution. For other genotypes, saline solution reduced shoot dry weight and the reduction percentage ranged from $40 \%$ to $85 \%$, depending on genotype.

Plant tolerance to salinity is usually evaluated in one of three ways: 1) the ability of a plant to survive on saline soils; 2) the absolute plant growth or yield; and 3) the relative growth or yield on saline soils as compared with that on non-saline soils (Maas, 1986). In Expt. 1, the salinity treatment was imposed during the vegetative stage after plants were well established in pots. Salinity stress caused growth reduction without any visible foliar salt damage, which may indicate that the salinity stress in Expt. 1 was mild to moderate depending on genotype. Based on growth reduction of plants irrigated with saline solution in comparison with non-saline nutrient solution, 'TAM Mild Habanero', 'Ben Villalon', and 'NuMex Primavera' had more than $50 \%$ reduction in shoot dry weight. Based on survival rate and growth reduction in Expt. 2, 'TAM Mild Habanero' and 'Ben Villalon' were again the most sensitive genotypes, whereas 'Early Jalapeño', 'AZ-20', Ancho 1, Ancho 2, and Cayenne 1 were relatively tolerant to salinity. Although 'NuMex Joe E. Parker' and 'NuMex Sandia' performed relatively well in Expt. 1, their survival rates and visual scores were low in Expt. 2. These results also indicate that mild to moderate salinity stresses such as in Expt. 1 might not be enough to distinguish differences in salinity tolerance among these genotypes. The performance of Ancho 1 and Ancho 2 in both experiments was similar with shoot growth reduced when irrigated with saline water.

The observed differences in visual quality in response to salinity between the two experiments even for the same genotype may be related to differences in seedling age. For example, 'NuMex Joe E. Parker' and 'NuMex Sandia' had different responses to salinity in the two experiments. The salinity treatments were initiated in Expt. 1 and Expt. 2 when seedlings were $42 \mathrm{~d}$ and $37 \mathrm{~d}$ old, respectively. In addition, seedlings in Expt. 2 grew more slowly compared with those in Expt. 1 as a result of initial soil salinity. Therefore, the seedlings in Expt. 2 were younger than those in Expt. 1 at the initiation of saline water treatment. Similar growth stage-dependent responses to salinity have also been reported in other species (Pasternak and Malach, 1994). In general, young seedlings are more sensitive to salinity stress than more mature plants. For instance, seedling growth of two bell pepper cultivars was significantly reduced at $10 \mathrm{~mm}$ $\mathrm{NaCl}\left(0.9 \mathrm{dS} \cdot \mathrm{m}^{-1}\right)$, whereas dry weight and plant height were reduced significantly at salinities higher than $25 \mathrm{~mm} \mathrm{NaCl}\left(2.3 \mathrm{dS} \cdot \mathrm{m}^{-1}\right)$ (Chartzoulakis and Klapaki, 2000).

The observed different responses and performance in the two experiments could also be related to differences in growing media (peatbased potting mix versus mineral soil). Soil chemical and physical properties such as $\mathrm{pH}$, salt accumulation, permeability, and porosity affect plant response to salinity (Shannon et al., 1994). Onion seedling emergence percents and growth were higher in loamy sand than silt loam under saline conditions (Miyamoto et al., 2010).

Leaf stomatal conductance. Leaf $g_{\mathrm{S}}$ was reduced by elevated salinity in all genotypes, although the extent of this reduction varied with genotype (Table 3). The lower leaf conductance was observed 2 weeks after saline water irrigation in more than half of the genotypes (data not shown). At the end of Expt. 1, Jalapeño 1, Jalapeño 2, and Serrano 2 had relatively high leaf conductance in plants irrigated with saline water compared with other genotypes (Table 3 ). However, these genotypes had lower leaf conductance measured at other times during the experiment (data not shown). In Expt. 2, the low leaf conductance of all genotypes irrigated with saline solution indicated that all plants were stressed by the elevated soil salinity. Seventeen of 20 genotypes had $g_{\mathrm{S}}$ values less than $50 \mathrm{mmol} \cdot \mathrm{m}^{-2} \cdot \mathrm{s}^{-1}$ (Table 3). For Habanero 1, Paprika, Serrano 2, and 'NuMex Primavera', the $g_{\mathrm{S}}$ values for the control plants were also low, which diminished the differences between the two treatments.

Table 2. Visual scores and shoot dry weight (DW) of 20 chile pepper seedlings irrigated with nutrient solution (control) or saline solution (salt) for 7 weeks (Expt. 2).

\begin{tabular}{|c|c|c|c|c|c|}
\hline Genotypes & Type & $\begin{array}{c}\text { Survival } \\
\text { control/salt }(\%)\end{array}$ & $\begin{array}{l}\text { Visual score } \\
\text { control/salt }\end{array}$ & $\begin{array}{c}\text { Shoot DW } \\
\text { control/salt }(\mathrm{g})\end{array}$ & $t$ test \\
\hline Ancho 1 & $\mathrm{BL}$ & $100 / 100$ & $5.0 / 4.8$ & $4.3 / 2.5$ & $* * * \mathrm{z}$ \\
\hline Ancho 2 & BL & $100 / 100$ & $5.0 / 4.9$ & $4.5 / 2.8$ & * \\
\hline Cayenne 1 & BL & $100 / 100$ & $5.0 / 2.4$ & $1.6 / 0.8$ & * \\
\hline Cayenne 2 & BL & $100 / 88$ & $4.8 / 4.2$ & $3.3 / 1.6$ & $* * *$ \\
\hline Green Chile 1 & $\mathrm{BL}$ & $75 / 50$ & $4.0 / 1.9$ & $1.5 / 0.6$ & NS \\
\hline Habanero 1 & BL & $100 / 38$ & $3.3 / 1.3$ & $0.7 / 0.4$ & - \\
\hline Jalapeño 1 & BL & $88 / 88$ & $4.4 / 2.3$ & $1.9 / 0.6$ & $* * *$ \\
\hline Jalapeño 2 & BL & $75 / 50$ & $4.2 / 2.0$ & $1.4 / 0.9$ & NS \\
\hline Paprika & BL & $100 / 75$ & $4.5 / 3.2$ & $1.6 / 1.1$ & NS \\
\hline Serrano 1 & BL & $100 / 75$ & $4.8 / 2.5$ & $3.0 / 0.8$ & $* * *$ \\
\hline Serrano 2 & BL & $100 / 50$ & $4.4 / 1.5$ & $1.6 / 0.3$ & $* * *$ \\
\hline Ben Villalon & $\mathrm{CV}$ & $75 / 50$ & $4.0 / 1.1$ & $1.6 / 0.2$ & $* *$ \\
\hline TAM Mild Habanero & $\mathrm{CV}$ & $38 / 0$ & $1.9 / 0.0$ & - & - \\
\hline Early Jalapeño & $\mathrm{CV}$ & $100 / 100$ & $4.8 / 2.9$ & $1.4 / 0.9$ & NS \\
\hline$A Z-20$ & $\mathrm{CV}$ & $100 / 100$ & $5.0 / 4.2$ & $2.9 / 2.5$ & NS \\
\hline NuMex 6-4 & $\mathrm{CV}$ & $100 / 88$ & $4.5 / 3.4$ & $3.2 / 1.1$ & $* * *$ \\
\hline NuMex Joe E. Parker & $\mathrm{CV}$ & $86 / 57$ & $4.5 / 1.7$ & $1.7 / 0.3$ & $* * *$ \\
\hline NuMex Primavera & $\mathrm{CV}$ & $100 / 57$ & $5.0 / 2.5$ & $1.4 / 0.8$ & * \\
\hline NuMex Nematador & $\mathrm{CV}$ & $86 / 33$ & $4.5 / 2.2$ & $2.5 / 0.6$ & $*$ \\
\hline NuMex Sandia & $\mathrm{CV}$ & $67 / 57$ & $2.8 / 1.4$ & $2.3 / 1.1$ & $* * *$ \\
\hline
\end{tabular}

z*,**,***, Ns indicates significant and nonsignificant at $P=0.05,0.01$, or 0.001 , respectively.

$\mathrm{BL}=$ breeding line; $\mathrm{CV}=$ cultivar.

Table 3. Leaf stomatal conductance $\left(g_{\mathrm{s}}\right)$ of 20 chile pepper seedlings irrigated with nutrient solution (control) or saline solution (salt) for 4 weeks (Expt. 1) and 7 weeks (Expt. 2).

\begin{tabular}{|c|c|c|c|c|c|}
\hline Genotypes & Type & $\begin{array}{l}g_{\mathrm{S}}(\text { Expt. 1) control/salt } \\
\left(\mathrm{mmol} \cdot \mathrm{m}^{-2} \cdot \mathrm{s}^{-1}\right)\end{array}$ & $t$ test & $\begin{array}{l}g_{\mathrm{S}}(\text { Expt. 2) control/salt } \\
\left(\mathrm{mmol} \cdot \mathrm{m}^{-2} \cdot \mathrm{s}^{-1}\right)\end{array}$ & $t$ test \\
\hline Ancho 1 & $\mathrm{BL}$ & $121 / 44$ & $* \mathrm{z}$ & $155 / 48$ & $* * *$ \\
\hline Ancho 2 & BL & $163 / 49$ & $* * *$ & $147 / 40$ & * \\
\hline Cayenne 1 & BL & $176 / 41$ & $*$ & $110 / 24$ & $*$ \\
\hline Cayenne 2 & $\mathrm{BL}$ & $60 / 46$ & NS & $146 / 73$ & $*$ \\
\hline Green Chile 1 & BL & - & - & $130 / 20$ & $* * *$ \\
\hline Habanero 1 & $\mathrm{BL}$ & $121 / 42$ & $*$ & $105 / 93$ & NS \\
\hline Jalapeño 1 & BL & $191 / 110$ & NS & $122 / 44$ & $*$ \\
\hline Jalapeño 2 & BL & 211/91 & NS & $96 / 41$ & $*$ \\
\hline Paprika & $\mathrm{BL}$ & $149 / 71$ & NS & $72 / 48$ & NS \\
\hline Serrano 1 & BL & $231 / 103$ & $*$ & $135 / 50$ & $* * *$ \\
\hline Serrano 2 & $\mathrm{BL}$ & $174 / 163$ & NS & $82 / 62$ & NS \\
\hline Ben Villalon & $\mathrm{CV}$ & $81 / 29$ & NS & $106 / 23$ & $*$ \\
\hline TAM Mild Habanero & $\mathrm{CV}$ & $132 / 87$ & * & $100 /-$ & - \\
\hline Early Jalapeño & $\mathrm{CV}$ & $131 / 65$ & $*$ & $155 / 38$ & $* * *$ \\
\hline AZ-20 & $\mathrm{CV}$ & $130 / 56$ & $*$ & $95 / 44$ & $*$ \\
\hline NuMex 6-4 & $\mathrm{CV}$ & $108 / 47$ & $*$ & $104 / 26$ & $* * *$ \\
\hline NuMex Joe E. Parker & $\mathrm{CV}$ & $145 / 27$ & $* * *$ & $89 / 43$ & $*$ \\
\hline NuMex Primavera & $\mathrm{CV}$ & $137 / 58$ & $*$ & $85 / 62$ & NS \\
\hline NuMex Nematador & $\mathrm{CV}$ & $101 / 53$ & $*$ & $49 / 18$ & $* * *$ \\
\hline NuMex Sandia & $\mathrm{CV}$ & $113 / 36$ & $* *$ & $111 / 29$ & $* * *$ \\
\hline
\end{tabular}

z*, **, ***, Ns indicates significant and nonsignificant at $P=0.05,0.01$, or 0.001 , respectively.

$\mathrm{BL}=$ breeding line; $\mathrm{CV}=$ cultivar. 
Table 4. Leachate salinity [electrical conductivity (EC)] and $\mathrm{pH}$ at the end of the experiments of 20 chile pepper seedlings irrigated with nutrient (control) or saline solution for 4 weeks (Expt. 1) and 7 weeks (Expt. 2).

\begin{tabular}{|c|c|c|c|c|c|}
\hline \multirow[b]{3}{*}{ Genotypes } & \multirow[b]{3}{*}{ Type } & \multirow{2}{*}{\multicolumn{2}{|c|}{ Expt. 1}} & \multirow{2}{*}{\multicolumn{2}{|c|}{$\frac{\text { Expt. } 2}{\text { EC }\left(\mathrm{dS} \cdot \mathrm{m}^{-1}\right)}$}} \\
\hline & & & & & \\
\hline & & $\overline{\mathrm{EC}\left(\mathrm{dS} \cdot \mathrm{m}^{-1}\right)}$ & $\mathrm{pH}$ & Week 1 & Week 6 \\
\hline Control $^{z}$ & & $5.10^{y}$ & 5.50 & 3.40 & 3.59 \\
\hline Ancho 1 & $\mathrm{BL}$ & $11.83 \mathrm{~g}^{\mathrm{x}}$ & $5.40 \mathrm{ab}$ & $4.58 \mathrm{j}$ & $15.60 \mathrm{bac}$ \\
\hline Ancho 2 & $\mathrm{BL}$ & $11.92 \mathrm{gf}$ & $5.11 \mathrm{ab}$ & $4.97 \mathrm{jih}$ & $13.93 \mathrm{bac}$ \\
\hline Cayenne 1 & $\mathrm{BL}$ & $12.78 \mathrm{edgcf}$ & $4.93 \mathrm{~b}$ & 5.62 fdiehcg & $13.23 \mathrm{bac}$ \\
\hline Cayenne 2 & $\mathrm{BL}$ & $11.00 \mathrm{~g}$ & $5.08 \mathrm{~b}$ & 5.68 fdiehcg & $11.50 \mathrm{c}$ \\
\hline Green Chile 1 & $\mathrm{BL}$ & - & - & 5.29 fjihg & $12.78 \mathrm{bc}$ \\
\hline Habanero 1 & $\mathrm{BL}$ & $10.88 \mathrm{~g}$ & $5.23 \mathrm{ab}$ & 5.49 fjdiehg & $13.87 \mathrm{bac}$ \\
\hline Jalapeño 1 & $\mathrm{BL}$ & 13.73 ebdgcf & $5.10 \mathrm{ab}$ & $6.14 \mathrm{fbdec}$ & $12.18 \mathrm{bc}$ \\
\hline Jalapeño 2 & $\mathrm{BL}$ & $12.06 \mathrm{gf}$ & $5.66 \mathrm{a}$ & $6.89 \mathrm{ba}$ & $17.83 \mathrm{ba}$ \\
\hline Paprika & $\mathrm{BL}$ & $12.40 \mathrm{egf}$ & $5.35 \mathrm{ab}$ & $6.37 \mathrm{bdec}$ & $16.20 \mathrm{bac}$ \\
\hline Serrano 1 & $\mathrm{BL}$ & $13.55 \mathrm{ebdgcf}$ & $5.15 \mathrm{ab}$ & 5.92 fbdehcg & $18.00 \mathrm{ba}$ \\
\hline Serrano 2 & $\mathrm{BL}$ & 13.66 ebdgcf & $5.26 \mathrm{ab}$ & $6.79 \mathrm{ba}$ & $18.93 \mathrm{a}$ \\
\hline Ben Villalon & $\mathrm{CV}$ & 15.74 bdac & $5.11 \mathrm{ab}$ & 5.37 fjiehg & $15.50 \mathrm{bac}$ \\
\hline TAM Mild Habanero & $\mathrm{CV}$ & $11.14 \mathrm{~g}$ & $5.33 \mathrm{ab}$ & $7.39 \mathrm{a}$ & - \\
\hline Early Jalapeño & $\mathrm{CV}$ & $12.62 \mathrm{edgf}$ & $5.32 \mathrm{ab}$ & $4.88 \mathrm{ji}$ & $12.68 \mathrm{bc}$ \\
\hline AZ-20 & $\mathrm{CV}$ & $16.58 \mathrm{a}$ & $5.14 \mathrm{ab}$ & 5.09 jihg & $13.93 \mathrm{bac}$ \\
\hline NuMex 6-4 & $\mathrm{CV}$ & $15.28 \mathrm{ba}$ & $5.10 \mathrm{ab}$ & $6.50 \mathrm{bdac}$ & $17.78 \mathrm{ba}$ \\
\hline NuMex Joe E. Parker & $\mathrm{CV}$ & 13.10 ebdgcf & $5.44 \mathrm{ab}$ & 5.89 fbdiehcg & $14.80 \mathrm{bac}$ \\
\hline NuMex Primavera & $\mathrm{CV}$ & 15.38 ebdac & $5.16 \mathrm{ab}$ & $6.63 \mathrm{bac}$ & $15.68 \mathrm{bac}$ \\
\hline NuMex Nematador & $\mathrm{CV}$ & $15.90 \mathrm{bac}$ & $5.18 \mathrm{ab}$ & $6.28 \mathrm{fbdec}$ & $15.23 \mathrm{bac}$ \\
\hline NuMex Sandia & $\mathrm{CV}$ & 15.08 ebdacf & $5.07 \mathrm{~b}$ & $6.08 \mathrm{fbdecg}$ & $16.55 \mathrm{bac}$ \\
\hline
\end{tabular}

${ }^{\text {zPooled from genotypes. }}$

${ }^{\mathrm{y}}$ Final leachate EC and $\mathrm{pH}$ for Expt. 1.

${ }^{x}$ Student-Newman-Keuls multiple comparisons at $P=0.05$ for all genotypes in salinity treatment.

$\mathrm{BL}=$ breeding line; $\mathrm{CV}=$ cultivar.

The most dramatic and readily measurable whole plant response to salinity is stomatal closure (Munns and Tester, 2008). The initial response of plants to salinity is similar to water stress, which is reflected in a reduced $g_{\mathrm{S}}$ (Munns, 2002). Under severe salinity stress, ions accumulate in plant tissues, leading to ion toxicity symptoms (Marschner, 1995). In Expt. 1, the reduction in growth in response to salinity stress was probably attributable, in part, to a decline in $g_{\mathrm{S}}$ and photosynthetic carbon assimilation. In Expt. 2, salinity stress was apparently more severe, leading to slower growth in all genotypes and seedling death in a few genotypes.

Leachate electrical conductivity and $\mathrm{pH}$. The leachate EC and $\mathrm{pH}$ were affected by salinity and genotype in Expt. 1 (Table 4). As salts accumulated in the root zone, reflected by the high leachate EC, $\mathrm{pH}$ also declined, especially when the commercial potting mix was used. The leachate EC in the control treatments ranged from 3.5 to $5.7 \mathrm{dS} \cdot \mathrm{m}^{-1}$ and $\mathrm{pH}$ from 5.3 to 5.7 among genotypes in Expt. 1. In Expt. 2, the final leachate EC (Week 6) ranged from 12 to $19 \mathrm{dS} \cdot \mathrm{m}^{-1}$ with 10 genotypes having a leachate EC higher than 15 $\mathrm{dS} \cdot \mathrm{m}^{-1}$. The initial leachate measured after two irrigations with a saline solution at 3.0 $\mathrm{dS} \cdot \mathrm{m}^{-1}$ ranged from 4.6 to $7.4 \mathrm{dS} \cdot \mathrm{m}^{-1}$. Variations in leachate EC were possibly caused by initial differences in soil salinity, plant growth, and the environmental conditions surrounding the pots. In Expt. 1, leachate $\mathrm{pH}$ had a strong negative correlation with leachate $\mathrm{EC}$, in which $\mathrm{pH}=-0.06 \mathrm{EC}+6.10$
$(P<0.0001)$ when plants were irrigated with saline solution. However, in Expt. 2, when loamy sand was used, there was no correlation between leachate $\mathrm{EC}$ and $\mathrm{pH}$, in which leachate $\mathrm{pH}$ ranged from 8.01 to 8.20 .

Regardless of the substrate, root zone salt accumulation, as indicated by leachate EC and $\mathrm{pH}$, occurred. Non-uniform salinity in the soil profile is unavoidable and the degree of non-uniformity depends on leaching fraction, irrigation management, and physical properties of the substrate (Maas, 1990). Soil permeability influences salt accumulation and distribution in the root zone and therefore results in differences in plant responses to salinity (Shannon et al., 1994). Our previous research also indicated this fact under two soil types (Niu et al., 2010) and a range of substrate types ranged from peat-based commercial potting mix to mineral soils on a number of ornamental plant species (Niu and Rodriguez, 2006a, 2006b; Niu et al., 2007).

In summary, the 20 genotypes of chile peppers responded to salinity differently. 'TAM Mild Habanero' and 'Ben Villalon' were most sensitive to salinity as evidenced by greater shoot growth reduction, low survival rates, and severe foliar salt damage when irrigated with saline solutions. 'AZ20', 'Early Jalapeño', Ancho 1, Ancho 2, Cayenne 1, and Cayenne 2 were relatively more tolerant than the rest of the genotypes. Further studies are needed to examine their response to salinity during other growth stages.

\section{Literature Cited}

Aktas, H., K. Abak, and I. Cakmak. 2006. Genotypic variation in the response of pepper to salinity. Sci. Hort. 110:260-266.

Chartzoulakis, K. and G. Klapaki. 2000. Response of two greenhouse pepper hybrids to $\mathrm{NaCl}$ salinity during different growth stages. Sci. Hort. 86:247-260.

Corgan, J., M. Wall, C. Cramer, T. Sammis, B. Lewis, and J. Schroeder. 2000. Bulb onion culture and management. New Mexico State University, Cooperative Extension Service, Circular 563.

Maas, E.V. 1986. Salt tolerance of plants. Applied Agricultural Research 1:12-26.

Maas, E.V. 1990. Crop salt tolerance, p. 262-304. In: Tanji, K.K. (ed.). Agricultural salinity assessment and management. ASCE Manuals and reports on engineering practice No. 71 . Amer. Soc. of Civil Engineers, New York, NY.

Maas, E.V. and G.J. Hoffman. 1977. Crop salt tolerance-Current assessment. J. Irrig. Drain. Div. 103:115-134.

Marschner, H. 1995. Mineral nutrition of higher plants. 2nd Ed. Academic Press, San Diego, CA.

Miyamoto, S., G. Niu, and I. Martinez. 2010. Salinity and specific ion effects on onion establishment in relation to disposal of desalting concentrates. Desalinization and Water Treatment 16:381-392.

Munns, R. 2002. Comparative physiology of salt and water stress. Plant Cell Environ. 25:239250 .

Munns, R. and M. Tester. 2008. Mechanisms of salinity tolerance. Annu. Rev. Plant Biol. 59: 651-681.

Niu, G. and D.S. Rodriguez. 2006a. Relative salt tolerance of five herbaceous perennials. HortScience 41:1493-1497.

Niu, G. and D.S. Rodriguez. 2006b. Relative salt tolerance of selected herbaceous perennials and groundcovers. Sci. Hort. 110:352-358.

Niu, G., D.S. Rodriguez, R. Cabrera, J. Jifon, D. Leskovar, and K. Crosby. 2010. Salinity and soil type effects on emergence and growth of pepper seedlings. HortScience 45:1265-1269.

Niu, G., D.S. Rodriguez, and Y.T. Wang. 2007. Salinity and growing medium regulate growth, morphology and ion uptake of Gaillardia aristata. J. Env. Hort. 25:89-94.

Pasternak, D. and Y.D. Malach. 1994. Crop irrigation with saline water, p. 599-622. In: Pessarakli, M. (ed.). Handbook of plant and crop stress. Marcel Dekker, New York, NY.

Phillips, R. 2003. Chile pepper growers' notes New Mexico State University Cooperative Extension Service, New Mexico Chile Task Force Report 10.

Rozema, J. and T. Flowers. 2008. Crops for a salinized world. Science 322:1478-1480.

SAS Institute. 2002. SAS/STAT software, Version 9.1. SAS Institute, Cary, NC.

Shannon, M.C., C.M. Grieve, and L.E. Francois. 1994. Whole-plant response to salinity, p. 199-244. In: Wilkinson, R.E. (ed.). Plant environment interaction. Marcel Dekker, New York, NY.

Villa-Castorena, M., A.L. Ulery, E.A. CatalanValencia, and M.D. Remmenga. 2003. Salinity and nitrogen rate effects on the growth and yield of chile pepper plants. Soil Sci. Soc. Amer. J. 67:1781-1789.

Wright, R.D. 1986. The pour-through nutrient extraction procedure. HortScience 21:227-229. 